\title{
Cancer Services During the COVID-19 Pandemic: Systematic Review of Patient's and Caregiver's Experiences
}

\author{
Symran Dhada' \\ Derek Stewart ${ }^{2}$ \\ Ejaz Cheema iD \\ Muhammad Abdul Hadi (iD) \\ Vibhu Paudyal (D) \\ 'College of Medical and Dental Sciences, \\ School of Pharmacy, University of \\ Birmingham, Birmingham, UK; ${ }^{2}$ College \\ of Pharmacy, QU Health, Qatar \\ University, Doha, Qatar
}

Purpose: Cancer patients have faced intersecting crises during the COVID-19 pandemic. This review aimed to examine patients' and caregivers' experiences of accessing cancer services during the pandemic and its perceived impact on their psychological wellbeing.

Patients and Methods: A protocol-led (CRD42020214906) systematic review was conducted by searching six databases including EMBASE, MEDLINE and CINAHL for articles published in English-language between 1/2020 and 12/2020. Data were extracted using a pilot-tested, structured data extraction form. Thematic synthesis of data was undertaken and reported as per the PRISMA guideline.

Results: A total of 1110 articles were screened, of which 19 studies met the inclusion criteria. Studies originated from 10 different countries including the US, UK, India and China. Extracted data were categorised into seven themes. Postponement and delays in cancer screening and treatment, drug shortages and inadequate nursing care were commonly experienced by patients. Hospital closures, resource constraints, national lockdowns and patient reluctance to use health services due to infection worries contributed to the delay. Financial and social distress, isolation, and spiritual distress were also commonly reported. Caregivers in addition felt anxious about infecting cancer patients with COVID-19.

Conclusion: Patients and caregivers experienced delays in cancer screening, treatment and care during the COVID-19 pandemic and negatively affected their psychological wellbeing. Their views and preferences should be accounted to minimise the impact of the current and any future pandemics and ensure resilient cancer services.

Protocol Registration: Published protocol registered with Centre for Review and Dissemination CRD42020214906 (https://www.crd.york.ac.uk/prospero/display_record.php? RecordID=214906).

Keywords: cancer care, cancer screening, COVID-19, coronavirus, patients, caregivers

\section{Introduction}

Coronavirus disease 2019 (COVID-19), caused by the novel severe acute respiratory syndrome coronavirus 2 (SARS-CoV-2), ${ }^{1}$ has challenged the resilience of healthcare systems and economies globally. The pandemic has placed an immense strain on cancer services, resulting in disruptions largely due to measures necessary to minimise patient exposure to the virus coupled with strains on health services resources. Such disruptions for cancer patients can accentuate the poor prognosis compared to noncancer patients. $^{2}$ Notably, the overall case fatality rate due to COVID-19 for cancer patients during initial phase of the pandemic was reported to be $23.4 \%(95 \% \mathrm{Cl}=9.7 \%$
Correspondence: Vibhu Paudyal

College of Medical and Dental Sciences,

School of Pharmacy, University of

Birmingham, Birmingham, BI5 2TT, UK

Tel +4401214142538

Email v.paudyal@bham.ac.uk 
to $40.5 \%)$ compared to $5.9 \%(95 \% \mathrm{Cl}=1.9 \%$ to $11.7 \%)$ for non-cancer patients. ${ }^{3}$ Data estimates suggest that a reduction of up to $85 \%$ in US-based cancer screening services at the height of the first wave (March-July 2020). ${ }^{4}$ In England, urgent referrals for suspected cancer were down $16 \%$ (348,000 referrals) compared with data in the previous year. ${ }^{5}$ Given that early diagnosis and timely access to appropriate treatment modality are critical factors for positive patient outcomes, ${ }^{2,6-8}$ The number of avoidable cancer-related deaths is therefore predicted to substantially increase. ${ }^{6}$ These service interruptions are also likely to impact negatively those receiving or awaiting palliative care.

The pandemic and the consequent disruption in health services have led many to suggest that cancer has become the "forgotten C". 9,10 Whilst current research places appropriate emphasis on the relationship between COVID-19 and treatment adjustments and survival outcomes, ${ }^{3,6-8,11,12}$ it is important to consider patient and caregiver views and experiences. These could inform the further development of resilient cancer services for the current and future pandemics. This systematic review aimed to examine patients' and caregivers' experiences of accessing cancer services during the COVID-19 pandemic and the perceived impact on psychological wellbeing.

\section{Methods}

The systematic review was conducted and reported in accordance with the recommendation of Preferred Reporting Items for Systematic Reviews and Meta-analyses (PRISMA) guidelines, ${ }^{13}$ based on a published protocol (CRD42020214906). Reporting was done as per PRISMA checklist [13] (electronic Supplementary Material 2).

\section{Literature Search}

CINAHL, EMBASE, MEDLINE, Google Scholar, Wellcome Open Research and Authorea (for unpublished studies and ongoing peer reviews) databases were searched systematically using medical subject headings (MeSH) and free-text keywords including "cancer", 'oncology, and 'Coronavirus", 'COVID-19' and related terms (electronic Supplementary Material 1) from January 2020 till December 2020. Boolean operators were used to refine the search.

\section{Inclusion and Exclusion Criteria}

Studies published in English on the views, experiences and perceived impact of COVID-19 on cancer screening and care from the perspectives of patients/public and/or their caregivers (both formal and informal) were included. The search was not restricted to any cancer types (including palliative care), settings or participant demography.

\section{Screening and Selection}

Initial screening of titles was conducted independently by two investigators (SD and VP), with any disagreements resolved through discussion and consultation with a third investigator where needed. Title screening was followed by abstract and full-text screening with reference to the inclusion and exclusion criteria.

\section{Data Extraction and Analysis}

Data were extracted by one author (SD) and confirmed by another author (VP) using a pilot tested, structured data collection form. A thematic synthesis was adopted to analyse the extracted data, which were reported into themes and subthemes. ${ }^{14}$

\section{Quality Assessment}

A Critical Appraisal Skills Programme (CASP) tool was used to assess the quality of qualitative studies ${ }^{15}$ and the "NIH Quality of Observational, Cohort and CrossSectional Studies Assessment Tool" for survey studies. ${ }^{16}$ Quality assessment was undertaken by SD and VP.

\section{Results}

\section{Characteristics and Quality of Included Studies}

The initial search yielded 1110 results, with $19^{17-35}$ included in data extraction and synthesis (Figure 1). Studies reported experiences from participants in 10 countries, largely Italy $(n=4)$ the US $(n=3)$, India $(n=3)$, the UK and the Netherlands $(n=2$ each). The majority of studies employed a crosssectional survey methodology $(\mathrm{n}=14)$ and five were qualitative (Tables 1 and 2). Results of quality assessment are presented in electronic Supplementary Material 3 and $\underline{4}$.

\section{Results of Thematic Synthesis}

Seven key themes of synthesised data and several subthemes were identified, relating to experiences of accessing cancer screening and diagnosis; experiences of accessing cancer treatment and care services; communication in relation to cancer care; perceived risks of infection; anxiety and fear; adverse impact on personal life, family and finances; resilience and coping mechanisms and caregivers' specific concerns (Table 3 ). 


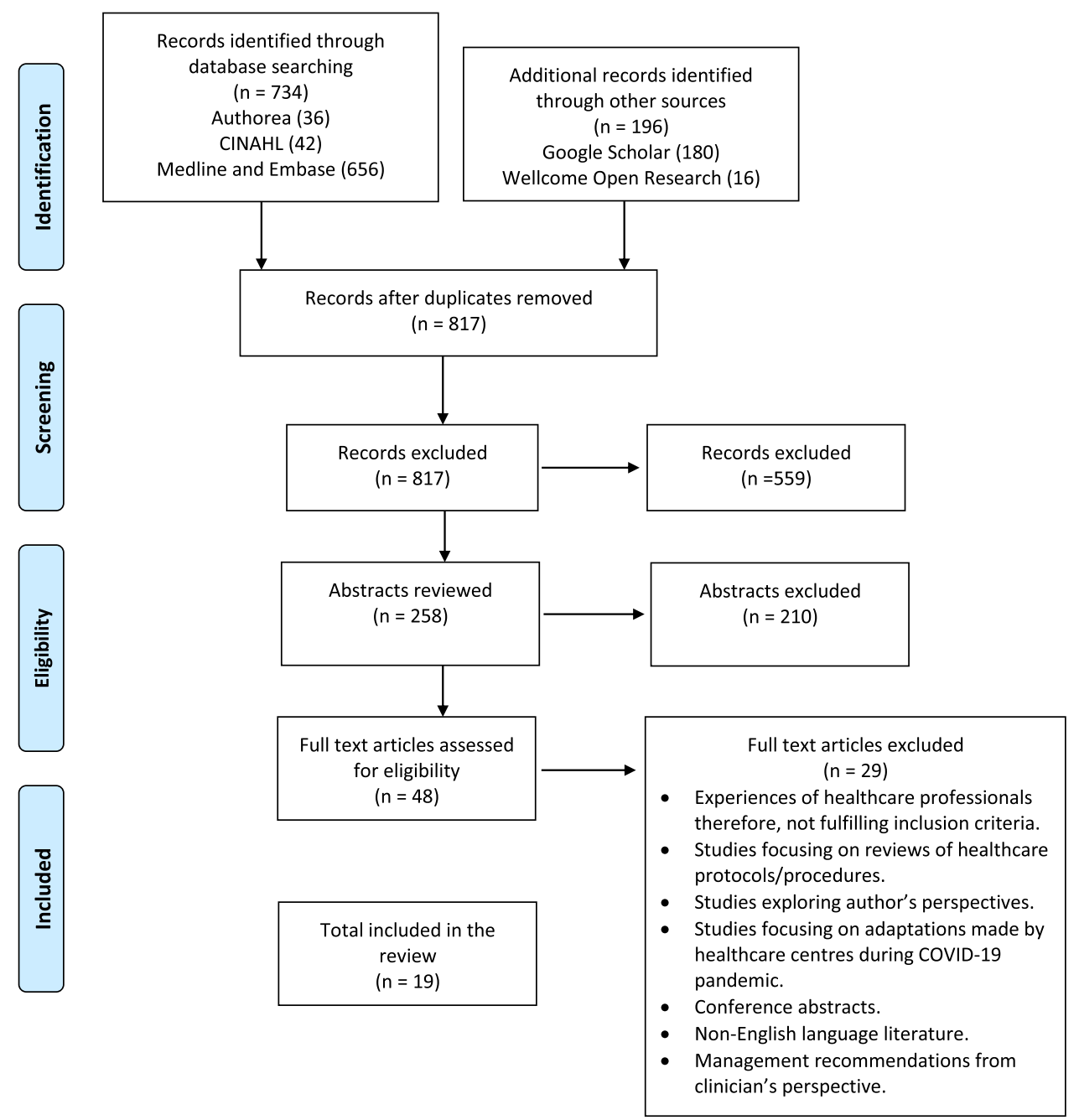

Figure I PRISMA diagram.

Notes: Adapted from Moher D, Liberati A, Tetzlaff J, Altman DG, The PRISMA Group (2009). Preferred Reporting Items for Systematic Reviews and Meta-Analyses: The PRISMA Statement. PLoS Med 6:7 el000097. doi:10.137I/journal.pmed I000097. ${ }^{13}$

\section{Experiences of Accessing Cancer Screening and Diagnostic Services}

Disruption to cancer screening and diagnosis was a commonly reported theme. A cross-sectional survey assessing the experiences of sarcoma patients at two of the largest specialist sarcoma centres in Europe reported that one-third experienced postponement of appointments or scans by at least three months. ${ }^{35}$ Patients also reported cancellations of routine follow-up clinic appointments in studies conducted in the UK and US. ${ }^{31,34}$ In a further two studies, patients expressed anxiety and fear due to postponement of cancer-related laboratory tests and diagnostic imaging. ${ }^{24,31}$ This overwhelming sense of anxiety amongst patients was further demonstrated in one study, with patients describing the pandemic as overshadowing the needs of families and severely affecting the quality and scope of cancer services. ${ }^{29}$ Some patients described their experiences of COVID-19 prevention taking precedence over cancer treatment and care. ${ }^{29}$

\section{Experiences of Accessing Cancer Treatment and Care Services}

Participants in most studies reported treatment delays, ${ }^{17,18,20,22,24-31}$ for a number of varied reasons including hospital cancellations, city lockdowns and COVID-19 testing requirements. Deferral of planned radiotherapy and very long appointment waiting were amongst the issues cited by a number of participants in a study conducted in India. ${ }^{30}$ Participants in a US study study reported that radiation, infusion therapies and 
Table I Characteristics of Qualitative Studies and Key Results

\begin{tabular}{|c|c|c|c|c|c|}
\hline $\begin{array}{l}\text { Study ID } \\
\& \text { (Country) }\end{array}$ & Study Aim(s) & $\begin{array}{l}\text { Study } \\
\text { Setting }\end{array}$ & $\begin{array}{l}\text { Study Design \& } \\
\text { Methodology }\end{array}$ & $\begin{array}{l}\text { Participant Numbers \& } \\
\text { Selection }\end{array}$ & Key Findings \\
\hline $\begin{array}{l}\text { Dhavale } 2020 \\
\text { (India) }^{22}\end{array}$ & $\begin{array}{l}\text { To describe the } \\
\text { challenges faced by } \\
\text { patients and caregivers } \\
\text { during the lockdown } \\
\text { due to the COVID-19 } \\
\text { pandemic. }\end{array}$ & $\begin{array}{l}\text { Palliative } \\
\text { care } \\
\text { centre. }\end{array}$ & $\begin{array}{l}\text { A qualitative study using an } \\
\text { exploratory approach to } \\
\text { review case notes followed } \\
\text { by framework analysis. }\end{array}$ & $\begin{array}{l}\text { Out of } 30 \text { patients, } 9 \\
\text { families that had received } \\
\text { care services during the } \\
\text { lockdown period were } \\
\text { invited to participate. }\end{array}$ & $\begin{array}{l}\text { A range of challenges were } \\
\text { faced by patients including: } \\
\text { physical distress due to lack } \\
\text { of availability of medicines } \\
\text { and nursing care; emotional } \\
\text { distress due to the } \\
\text { interruption of cancer } \\
\text { treatment; financial and } \\
\text { social distress about loss of } \\
\text { incomes, isolation; and } \\
\text { spiritual distress due to the } \\
\text { uncertainty of rites as well } \\
\text { as fulfilment of last wishes. } \\
\text { Three key themes were } \\
\text { identified: swinging on the } \\
\text { path of fear to adaptation, } \\
\text { left-alone at emotional } \\
\text { distances and care system } \\
\text { confusion, and decreased } \\
\text { quality of care. }\end{array}$ \\
\hline $\begin{array}{l}\text { Mirlashari } \\
2020 \\
(\text { Iran })^{29}\end{array}$ & $\begin{array}{l}\text { To investigate the } \\
\text { perspectives of } \\
\text { children with cancer } \\
\text { and their family in the } \\
\text { era of the COVID-19 } \\
\text { pandemic. }\end{array}$ & $\begin{array}{l}\text { Paediatric } \\
\text { hospital. }\end{array}$ & $\begin{array}{l}\text { Semi-structured, telephone } \\
\text { interviews followed by } \\
\text { thematic analysis. }\end{array}$ & $\begin{array}{l}\text { 2I participants: five } \\
\text { children, thirteen mothers, } \\
\text { a father and three } \\
\text { paediatric oncology nurses } \\
\text { were selected using the } \\
\text { purposive sampling } \\
\text { technique. }\end{array}$ & $\begin{array}{l}\text { The children expressed } \\
\text { their concerns about being } \\
\text { exposed to an unknown } \\
\text { and enormous threat. They } \\
\text { pointed out other } \\
\text { significant concerns, such } \\
\text { as changes in the treatment } \\
\text { process, the lack of } \\
\text { effective treatment, and } \\
\text { how the disease has } \\
\text { become so widespread. }\end{array}$ \\
\hline $\begin{array}{l}\text { Hyland } 2020 \\
\text { (United } \\
\text { States) }^{28}\end{array}$ & $\begin{array}{l}\text { To characterise the } \\
\text { behavioural and } \\
\text { psychosocial responses } \\
\text { of people with } \\
\text { advanced lung cancer } \\
\text { to the COVID-19 } \\
\text { pandemic. }\end{array}$ & $\begin{array}{l}\text { Cancer } \\
\text { centre. }\end{array}$ & $\begin{array}{l}\text { Baseline questionnaire and } \\
\text { semi-structured interview } \\
\text { were conducted and } \\
\text { repeated after one month. }\end{array}$ & I5 patients. & $\begin{array}{l}\text { Several themes emerged } \\
\text { from the data: cancer as } \\
\text { the primary health threat, } \\
\text { changes in oncology } \\
\text { practice and access to } \\
\text { cancer care, awareness of } \\
\text { mortality and perceptions } \\
\text { of risk, behavioural and } \\
\text { psychosocial responses to } \\
\text { COVID-I9, sense of loss/ } \\
\text { mourning and positive } \\
\text { reinterpretation/greater } \\
\text { appreciation of life. All } \\
\text { participants reported } \\
\text { changing their behaviour in } \\
\text { response to COVID-19. }\end{array}$ \\
\hline
\end{tabular}

(Continued) 
Table I (Continued).

\begin{tabular}{|c|c|c|c|c|c|}
\hline $\begin{array}{l}\text { Study ID } \\
\& \text { (Country) }\end{array}$ & Study Aim(s) & $\begin{array}{l}\text { Study } \\
\text { Setting }\end{array}$ & $\begin{array}{l}\text { Study Design \& } \\
\text { Methodology }\end{array}$ & $\begin{array}{l}\text { Participant Numbers \& } \\
\text { Selection }\end{array}$ & Key Findings \\
\hline $\begin{array}{l}\text { AlWaheidi } \\
2020 \\
(\text { Gaza })^{18}\end{array}$ & $\begin{array}{l}\text { To assess whether } \\
\text { COVID-19 could lead } \\
\text { to further inequity in } \\
\text { cancer care and poorer } \\
\text { outcomes for } \\
\text { Palestinians with } \\
\text { cancer. }\end{array}$ & $\begin{array}{l}\text { Tertiary } \\
\text { care } \\
\text { setting. }\end{array}$ & $\begin{array}{l}\text { Semi-structured qualitative } \\
\text { interviews were conducted } \\
\text { prior to the introduction } \\
\text { of COVID-19. The women } \\
\text { were then followed-up in } \\
\text { order to examine the } \\
\text { changes in health and } \\
\text { experiences of care. }\end{array}$ & $\begin{array}{l}20 \text { women with a breast } \\
\text { cancer diagnosis between } \\
2017 \text { and } 2018 \text {. }\end{array}$ & $\begin{array}{l}\text { A number of women } \\
\text { expressed concerns about } \\
\text { catching COVID-19 in the } \\
\text { hospital setting. New } \\
\text { concerns emerged about } \\
\text { the impact of COVID-19 } \\
\text { on treatment. }\end{array}$ \\
\hline $\begin{array}{l}\text { Casanova } \\
2020 \\
(\text { Italy })^{19}\end{array}$ & $\begin{array}{l}\text { To assess the } \\
\text { perception of risks and } \\
\text { level of stress } \\
\text { concerning COVID-19 } \\
\text { amongst young patients } \\
\text { with cancer. }\end{array}$ & $\begin{array}{l}\text { Paediatric } \\
\text { oncology } \\
\text { unit. }\end{array}$ & $\begin{array}{l}\text { Semi-structured } \\
\text { qualitative, online } \\
\text { questionnaire. }\end{array}$ & $\begin{array}{l}75 \text { patients: } 25 \text { were } \\
\text { receiving treatment, } 25 \\
\text { were in follow-up and had } \\
\text { completed their treatment } \\
\text { and } 25 \text { were healthy peers. }\end{array}$ & $\begin{array}{l}\text { Whilst the majority of } \\
\text { healthy peers did not } \\
\text { expect to be affected by } \\
\text { the virus, a large } \\
\text { proportion of patients } \\
\text { (more than those in follow- } \\
\text { up), were worried and felt } \\
\text { at risk of severe } \\
\text { complications. Most } \\
\text { responders in all three } \\
\text { groups reported that they } \\
\text { changed their daily habits. }\end{array}$ \\
\hline
\end{tabular}

surgical tumour removal were subject to severe disruption. $^{31}$ The impact on cancer surgery was highlighted in a US study, where 10 of 38 participants experiencing delays for ovarian cancer surgery. ${ }^{24}$ A study conducted at a tertiary-care referral hospital in Italy reported a median surgery waiting time of 53 days (IQR: 35-72 days) which was reported to be a marked increase on pre-pandemic waiting times. ${ }^{26}$

A study based in India reported additional issues of access including the deferral of nutritionist input, lack of availability of psychological counselling and peer group support services. $^{30}$ There was a dearth of availability to online counselling services.

Emotional distress was common in patients who had experienced disruption. ${ }^{28}$ The uncertainty surrounding medication availability and the lack of nursing care available for patients was an issue, particularly for those living alone. ${ }^{22,30}$ For example, patients with cervical and oral cancer struggled to source certain dressing materials and had utilise defective dressings. $^{22}$ Family and friends were prohibited from accompanying patients to appointments and visiting inpatients, leading to distress for both. In a study conducted at a palliative care centre in the US, participants likened the experience to being "prisoners in a cage". 21

\section{Communication in Relation to Cancer Care}

Disruptions to regular communications between patients and health services were commonly reported, with many studies reporting the use of remote forms of communications including telecommunication and telephone. ${ }^{17,20,22,30,35}$ Patients identified positive aspects of telecommunication for example, the ease of accessing care from the privacy and comfort of one's home and the ability to maintain physical distance. ${ }^{22}$ The majority of patients in one study hoped for continuation of online services post-pandemic. ${ }^{25}$ In another study, almost two-thirds of patients felt that they were still able to contact the healthcare team and so expressed feelings of reassurance. ${ }^{35}$ However, in one study conducted in India, patients reported difficulties in booking virtual appointments and unpredictable network issues. ${ }^{30}$

\section{Anxiety, Fear and Perceived Risk of Infection}

Feelings of anxiety and fear surrounding the pandemic were common, with eighteen studies referencing changes in emotional and psychological functioning. ${ }^{17-30,32-35}$ Approximately $55 \%$ of the 204 participants in one study 
Table 2 Characteristics of Quantitative Studies and Key Results

\begin{tabular}{|c|c|c|c|c|c|}
\hline $\begin{array}{l}\text { Study ID \& } \\
\text { (Country) }\end{array}$ & Study Aim(s) & $\begin{array}{l}\text { Study } \\
\text { Setting }\end{array}$ & $\begin{array}{l}\text { Study Design and } \\
\text { Methodology }\end{array}$ & $\begin{array}{l}\text { Participant } \\
\text { Numbers and } \\
\text { Selection }\end{array}$ & Key Findings \\
\hline $\begin{array}{l}\text { AlShahrani } \\
2020 \\
\text { (Saudi Arabia) }^{17}\end{array}$ & $\begin{array}{l}\text { To assess the impact of } \\
\text { the COVID-I9 } \\
\text { pandemic on children } \\
\text { with in terms of the } \\
\text { medical service } \\
\text { provided, precautionary } \\
\text { measures implemented } \\
\text { by the hospital cancer } \\
\text { unit to prevent the } \\
\text { spread of infection, the } \\
\text { acceptance of virtual } \\
\text { platforms and the } \\
\text { psychological and } \\
\text { mental impact. }\end{array}$ & $\begin{array}{l}\text { Tertiary } \\
\text { institution } \\
\text { within } \\
\text { a hospital } \\
\text { setting. }\end{array}$ & $\begin{array}{l}\text { Cross-sectional } \\
\text { observational study. } \\
\text { Participating parents } \\
\text { were asked to complete } \\
\text { a booklet type survey } \\
\text { questionnaire at the } \\
\text { clinic visit or via } \\
\text { a virtual platform. }\end{array}$ & $\begin{array}{l}204 \text { cancer patients } \\
\text { between 0-14 years of } \\
\text { age diagnosed with or } \\
\text { recently diagnosed with } \\
\text { cancer. }\end{array}$ & $\begin{array}{l}63 \% \text { of patients reported } \\
\text { a delay in treatment received } \\
\text { during the COVID-19 } \\
\text { pandemic. Key reasons include } \\
\text { hospital cancellations or } \\
\text { procedure delays. A third of } \\
\text { patients ( } 30.8 \% \text { ) reported lack } \\
\text { of cancer support and } \\
\text { shortage of medications during } \\
\text { the pandemic. Almost all were } \\
\text { fearful of contracting the virus } \\
\text { in healthcare settings and over } \\
80 \% \text { experienced an adverse } \\
\text { impact on quality of life. }\end{array}$ \\
\hline $\begin{array}{l}\text { Swainston } 2020 \\
\text { (United } \\
\text { Kingdom) }^{34}\end{array}$ & $\begin{array}{l}\text { To explore the effect of } \\
\text { disruption to scheduled } \\
\text { oncology services and } \\
\text { the UK government } \\
\text { shielding letter on } \\
\text { emotional and cognitive } \\
\text { vulnerability amongst } \\
\text { a group of women } \\
\text { affected by primary } \\
\text { breast cancer; examine } \\
\text { the relationship } \\
\text { between COVID-19 } \\
\text { related emotional } \\
\text { vulnerability (COVID- } \\
\text { EMV) and general } \\
\text { anxiety, depression and } \\
\text { perceived cognitive } \\
\text { function. }\end{array}$ & $\begin{array}{l}\text { Breast cancer } \\
\text { unit. }\end{array}$ & $\begin{array}{l}\text { Cross-sectional study } \\
\text { design. Participants } \\
\text { were asked to complete } \\
\text { a series of online } \\
\text { questionnaires. }\end{array}$ & $\begin{array}{l}234 \text { women with } \\
\text { a diagnosis of primary } \\
\text { breast cancer were } \\
\text { recruited through } \\
\text { voluntary sampling } \\
\text { using advertisements } \\
\text { placed on support } \\
\text { platforms. }\end{array}$ & $\begin{array}{l}\text { About a third ( } 31.6 \%) \text { had } \\
\text { been impacted by disruption } \\
\text { to their scheduled oncology } \\
\text { services (for example, had } \\
\text { appointments cancelled or } \\
\text { delivered over the phone). } \\
\text { Disruption to scheduled } \\
\text { oncology services had } \\
\text { a significant main effect on } \\
\text { women's COVID-EMV; } \\
\text { a measure of COVID-I9 } \\
\text { related emotional vulnerability } \\
\text { their general anxiety and } \\
\text { depression. Women who } \\
\text { experienced severe disruption } \\
\text { showed greater levels of } \\
\text { general emotional vulnerability } \\
\text { and COVID-EMV. }\end{array}$ \\
\hline $\begin{array}{l}\text { Desideri } 2020 \\
\left(^{(\text {Italy })^{2 \mid}}\right.\end{array}$ & $\begin{array}{l}\text { To prospectively assess } \\
\text { patient satisfaction } \\
\text { using patient reported } \\
\text { measures (PREMs) } \\
\text { about doctor-patient } \\
\text { interaction in a high- } \\
\text { volume radiation } \\
\text { therapy and oncology } \\
\text { centre during the } \\
\text { COVID-19 pandemic. }\end{array}$ & $\begin{array}{l}\text { Radiation } \\
\text { oncology unit. }\end{array}$ & $\begin{array}{l}\text { A prospective } \\
\text { monocentre study. } \\
\text { Surveys consisting of } \\
\text { two validated } \\
\text { questionnaires (EORTC } \\
\text { QLQ-C30 and FACIT- } \\
\text { TS-G version I) and I4 } \\
\text { specific questions were } \\
\text { administered to the } \\
\text { recruited outpatients. }\end{array}$ & 125 patients. & $\begin{array}{l}\text { The average Global Health } \\
\text { Status score (GHS) was } 61.67 \text {. } \\
\text { Emotional functioning, social } \\
\text { and cognitive domains } \\
\text { obtained scores of } 75.48 \text {, } \\
80.13 \text { and } 84.67 \text {, respectively. } \\
\text { Majority of patients ( } 89.6 \% \text { ) } \\
\text { rated their treatment as good, } \\
\text { very good or excellent. } \\
\text { Despite stringent measures to } \\
\text { contain the spread of COVID- } \\
\text { 19, there was a high level of } \\
\text { cancer outpatient satisfaction. }\end{array}$ \\
\hline
\end{tabular}

(Continued) 
Table 2 (Continued).

\begin{tabular}{|c|c|c|c|c|c|}
\hline $\begin{array}{l}\text { Study ID \& } \\
\text { (Country) }\end{array}$ & Study Aim(s) & $\begin{array}{l}\text { Study } \\
\text { Setting }\end{array}$ & $\begin{array}{l}\text { Study Design and } \\
\text { Methodology }\end{array}$ & $\begin{array}{l}\text { Participant } \\
\text { Numbers and } \\
\text { Selection }\end{array}$ & Key Findings \\
\hline $\begin{array}{l}\text { Guven at al, } \\
2020 \\
\left(\text { Turkey) }^{27}\right.\end{array}$ & $\begin{array}{l}\text { To assess the } \\
\text { perspectives and fears } \\
\text { of cancer patients about } \\
\text { COVID-19. }\end{array}$ & $\begin{array}{l}\text { Outpatient } \\
\text { infusion } \\
\text { chemotherapy } \\
\text { unit. }\end{array}$ & $\begin{array}{l}\text { Questionnaire } \\
\text { consisting of } 13 \\
\text { multiple-choice } \\
\text { questions. }\end{array}$ & $\begin{array}{l}250 \text { adult cancer } \\
\text { patients. A response } \\
\text { rate of } 78 \% \text { (195/250) } \\
\text { was achieved. }\end{array}$ & $\begin{array}{l}\text { Most patients saw treating } \\
\text { oncologists at least once during } \\
\text { the pandemic, mostly in hospital. } \\
\text { Almost all patients had some } \\
\text { degree of COVID-1 } 9 \text { fear and } \\
\text { more than } 80 \% \text { expected } \\
\text { disruptions in cancer care. }\end{array}$ \\
\hline $\begin{array}{l}\text { Schellekens } \\
2020 \\
\text { (Netherlands) }^{33}\end{array}$ & $\begin{array}{l}\text { To explore experiences } \\
\text { with the COVID-19 } \\
\text { pandemic in patients or } \\
\text { family members who } \\
\text { sought help at a mental } \\
\text { healthcare institute for } \\
\text { psycho-oncology. }\end{array}$ & $\begin{array}{l}\text { Mental health } \\
\text { institute } \\
\text { specialising in } \\
\text { psycho- } \\
\text { oncology care. }\end{array}$ & $\begin{array}{l}\text { 12-item survey } \\
\text { assessing the } \\
\text { psychosocial burden of } \\
\text { the COVID-19 } \\
\text { pandemic followed by } \\
\text { thematic analysis. }\end{array}$ & $\begin{array}{l}871 \text { patients invited, } \\
274 \text { responded ( } 233 \\
\text { patients and } 4 \text { I family } \\
\text { members). A response } \\
\text { rate of } 31.5 \% \text { achieved. }\end{array}$ & $\begin{array}{l}\text { The pandemic added uncertainty } \\
\text { for many patients. } 46 \% \text { of } \\
\text { patients feared not being able to } \\
\text { say farewell to family and friends } \\
\text { in case of dying from COVID- } 19 . \\
36 \% \text { of patients described feeling } \\
\text { lonely which stimulated their } \\
\text { worries regarding cancer. A large } \\
\text { proportion of patients felt more } \\
\text { at ease because of lockdown. }\end{array}$ \\
\hline $\begin{array}{l}\text { Greco } 2020 \\
(\text { Italy })^{26}\end{array}$ & $\begin{array}{l}\text { To investigate the health- } \\
\text { related quality of life of } \\
\text { uro-oncologic patients } \\
\text { whose surgery was } \\
\text { postponed without being } \\
\text { rescheduled during the } \\
\text { COVID-19 pandemic. }\end{array}$ & $\begin{array}{l}\text { Tertiary-care } \\
\text { referral } \\
\text { hospital. }\end{array}$ & $\begin{array}{l}\text { SF-36 online } \\
\text { questionnaire } \\
\text { measuring eight } \\
\text { domains. }\end{array}$ & $\begin{array}{l}50 \text { patients }(70 \% \\
\text { response rate). }\end{array}$ & $\begin{array}{l}86 \% \text { of patients reported an } \\
\text { almost intact physical function } \\
\text { but a significant emotional } \\
\text { alteration characterised by } \\
\text { a prevalence of anxiety and } \\
\text { loss of energy. }\end{array}$ \\
\hline $\begin{array}{l}\text { Mitra } 2020 \\
\left(_{\text {India })^{30}}\right.\end{array}$ & $\begin{array}{l}\text { To study the challenges } \\
\text { faced by cancer patients } \\
\text { in India during the } \\
\text { COVID-19 pandemic } \\
\text { and assess the } \\
\text { effectiveness of adopted } \\
\text { interventions. }\end{array}$ & Hospital. & $\begin{array}{l}\text { Cross-sectional study. } \\
\text { Participants completed } \\
\text { an online pre- } \\
\text { structured } \\
\text { questionnaire. Data } \\
\text { analysed using } \\
\text { descriptive statistics. }\end{array}$ & $\begin{array}{l}100 \text { randomly selected } \\
\text { cancer patients in } \\
\text { different stages of } \\
\text { treatment and follow- } \\
\text { up. ( } 36 \% \text { response } \\
\text { rate). }\end{array}$ & $\begin{array}{l}92 \% \text { of patients reported an } \\
\text { increase in anxiety levels. } \\
\text { Reasons include: fear of } \\
\text { COVID-19, fear of their } \\
\text { inherent disease getting } \\
\text { aggravated due to treatment } \\
\text { delays, fear of death and fear of } \\
\text { losing job and financial crisis } \\
\text { for family members. }\end{array}$ \\
\hline $\begin{array}{l}\text { Younger } 2020 \\
\text { (United } \\
\text { Kingdom) }\end{array}$ & $\begin{array}{l}\text { To assess the impact of } \\
\text { the COVID-19 } \\
\text { pandemic on care } \\
\text { experiences, worry and } \\
\text { health-related quality of } \\
\text { life (HRQoL) in patients } \\
\text { with sarcomas. }\end{array}$ & $\begin{array}{l}\text { Medical } \\
\text { oncology and } \\
\text { radiation } \\
\text { oncology } \\
\text { departments } \\
\text { at two } \\
\text { sarcoma } \\
\text { centres. }\end{array}$ & Cross-sectional survey. & $\begin{array}{l}350 \text { patients. Response } \\
\text { rate of } 44 \% .\end{array}$ & $\begin{array}{l}\text { Patients identified the following } \\
\text { care modifications as a result of } \\
\text { the pandemic: telemedicine } \\
\text { (74\%), postponement of } \\
\text { appointments/scans ( } 34 \%) \text { and } \\
\text { treatment (10\%). Worry about } \\
\text { COVID-19 infection was } \\
\text { moderately high (5.8/10). } \\
\text { Cancer-related worry, low } \\
\text { resilient coping and uncertainty } \\
\text { about treatment intent were } \\
\text { associated with COVID-19 } \\
\text { worry. }\end{array}$ \\
\hline
\end{tabular}

(Continued) 
Table 2 (Continued).

\begin{tabular}{|c|c|c|c|c|c|}
\hline $\begin{array}{l}\text { Study ID \& } \\
\text { (Country) }\end{array}$ & Study Aim(s) & $\begin{array}{l}\text { Study } \\
\text { Setting }\end{array}$ & $\begin{array}{l}\text { Study Design and } \\
\text { Methodology }\end{array}$ & $\begin{array}{l}\text { Participant } \\
\text { Numbers and } \\
\text { Selection }\end{array}$ & Key Findings \\
\hline $\begin{array}{l}\text { Ghosh } 2020 \\
\text { (India) }^{25}\end{array}$ & $\begin{array}{l}\text { To analyse patients' } \\
\text { willingness to continue } \\
\text { chemotherapy during } \\
\text { the pandemic and } \\
\text { identify factors } \\
\text { influencing decisions. }\end{array}$ & $\begin{array}{l}\text { Hospital } \\
\text { medical } \\
\text { oncology } \\
\text { department. }\end{array}$ & $\begin{array}{l}\text { A prospective } \\
\text { observational study. } \\
\text { Questionnaire-based } \\
\text { survey given to eligible } \\
\text { patients. }\end{array}$ & $\begin{array}{l}302 \text { patients, }>18 \text { years, } \\
\text { undergoing systemic } \\
\text { therapy for solid } \\
\text { malignancies and who } \\
\text { visited the centre } \\
\text { during lockdown ( } 1^{\text {st }} \text { - } \\
10^{\text {th }} \text { April 2020). }\end{array}$ & $\begin{array}{l}203 \text { patients wanted to } \\
\text { continue chemotherapy, } 40 \\
\text { wanted to defer and } 56 \\
\text { wanted the physician to } \\
\text { decide. The worry about } \\
\text { catching COVID-19 was high } \\
\text { in those with controlled } \\
\text { disease. }\end{array}$ \\
\hline $\begin{array}{l}\text { Qian } 2020 \\
(\text { China })^{32}\end{array}$ & $\begin{array}{l}\text { To explore the intensity } \\
\text { of physical and mental } \\
\text { distress among cancer } \\
\text { patients during the } \\
\text { epidemic. }\end{array}$ & $\begin{array}{l}\text { Hospital } \\
\text { radiation } \\
\text { oncology } \\
\text { department. }\end{array}$ & $\begin{array}{l}53 \text { question survey } \\
\text { assessing patient's } \\
\text { perception of the } \\
\text { impact of COVID-19 } \\
\text { using the Edmonton } \\
\text { Symptom Assessment } \\
\text { Scale (ESAS) and the } \\
\text { Hospital Anxiety and } \\
\text { Depression Scale } \\
\text { (HADS). }\end{array}$ & $\begin{array}{l}\text { I29 confirmed cancer } \\
\text { patients. } \\
\text { Response rate of } 64.5 \% \text {. }\end{array}$ & $\begin{array}{l}\text { All symptoms assessment } \\
\text { scores on ESAS were mild } \\
\text { except financial distress. The } \\
\text { majority of patients expressed } \\
\text { fear of becoming infected } \\
\text { themselves }(85 \%) \text { or their } \\
\text { family member }(91 \%) .127 \\
\text { participants reported that } \\
\text { their life was affected by } \\
\text { COVID- } 19 \text { and } 91 \text { reported } \\
\text { they needed mental health } \\
\text { support. }\end{array}$ \\
\hline $\begin{array}{l}\text { Frey } 2020 \\
\text { (United } \\
\text { States) }\end{array}$ & $\begin{array}{l}\text { To evaluate the } \\
\text { experience of women } \\
\text { with Ovarian cancer } \\
\text { during the Coronavirus } \\
\text { disease } 2019 \text { pandemic. }\end{array}$ & $\begin{array}{l}\text { Oncology } \\
\text { department. }\end{array}$ & $\begin{array}{l}\text { Online survey focussing } \\
\text { on treatment } \\
\text { interruptions and } \\
\text { quality of life. }\end{array}$ & $\begin{array}{l}603 \text { women with } \\
\text { current or previous } \\
\text { diagnosis of cancer. } 92 \% \\
\text { response rate. }\end{array}$ & $\begin{array}{l}\text { I } 75 \text { participants experienced } \\
\text { a delay in some component of } \\
\text { their cancer care. } 133 \\
\text { participants had a delayed } \\
\text { physician appointment. } 285 \\
\text { participants reported } \\
\text { borderline anxiety and } 147 \\
\text { reported borderline } \\
\text { depression. }\end{array}$ \\
\hline $\begin{array}{l}\text { Papautsky } 2020 \\
\text { (United }^{31} \\
\text { States) }\end{array}$ & $\begin{array}{l}\text { To assess healthcare } \\
\text { needs of breast cancer } \\
\text { patients requiring } \\
\text { access to crucial } \\
\text { services during the } \\
\text { COVID-19 pandemic. }\end{array}$ & $\begin{array}{l}\text { Oncology } \\
\text { department. }\end{array}$ & 50-item survey. & $\begin{array}{l}609 \text { adult breast cancer } \\
\text { survivors. Snowball } \\
\text { sampling technique } \\
\text { used to recruit } \\
\text { participants. }\end{array}$ & $\begin{array}{l}44 \% \text { of participants reported } \\
\text { cancer treatment delays. } 30 \% \\
\text { of respondents reported } \\
\text { delays in hospital or clinic- } \\
\text { based cancer therapies. }\end{array}$ \\
\hline $\begin{array}{l}\text { De Joode } 2020 \\
\text { (Netherlands) }^{20}\end{array}$ & $\begin{array}{l}\text { To assess the impact of } \\
\text { the COVID-I9 } \\
\text { pandemic on patients } \\
\text { with cancer and the } \\
\text { consequences for their } \\
\text { treatment. }\end{array}$ & Hospital. & $\begin{array}{l}\text { Online survey } \\
\text { consisting of } 20 \\
\text { questions on four } \\
\text { topics: patients' } \\
\text { characteristics, contact } \\
\text { with the hospital, } \\
\text { consequences of the } \\
\text { COVID-19 pandemic } \\
\text { and concerns about } \\
\text { COVID-19. }\end{array}$ & $\begin{array}{l}5302 \text { patients with } \\
\text { cancer. }\end{array}$ & $\begin{array}{l}30 \% \text { of patients reported } \\
\text { consequences for their } \\
\text { oncological treatment or } \\
\text { follow-up. In most cases, this } \\
\text { resulted in conversion from } \\
\text { hospital visits to consultation } \\
\text { by video or phone. } \\
\text { Chemotherapy ( } 30 \%) \text { and } \\
\text { immunotherapy ( } 32 \%) \text { were } \\
\text { most frequently adjusted. }\end{array}$ \\
\hline
\end{tabular}

(Continued) 
Table 2 (Continued).

\begin{tabular}{|l|l|l|l|l|l|}
\hline $\begin{array}{l}\text { Study ID \& } \\
\text { (Country) }\end{array}$ & Study Aim(s) & $\begin{array}{l}\text { Study } \\
\text { Setting }\end{array}$ & $\begin{array}{l}\text { Study Design and } \\
\text { Methodology }\end{array}$ & $\begin{array}{l}\text { Participant } \\
\text { Numbers and } \\
\text { Selection }\end{array}$ & Key Findings \\
\hline $\begin{array}{l}\text { Falcone 2020 } \\
(\text { Italy) })^{23}\end{array}$ & $\begin{array}{l}\text { To explore the impact } \\
\text { of the COVID-19 } \\
\text { pandemic on emotional } \\
\text { well-being and quality of } \\
\text { life of cancer patients. }\end{array}$ & $\begin{array}{l}\text { Thyroid cancer } \\
\text { centre. }\end{array}$ & $\begin{array}{l}\text { Two online } \\
\text { questionnaires: a 21- } \\
\text { item questionnaire and } \\
\text { EORTC QLQ-C30 } \\
\text { questionnaire. }\end{array}$ & $\begin{array}{l}\text { I37 patients. } \\
\text { Response rates were } \\
51 \% \text { and 44.5\% for each } \\
\text { questionnaire } \\
\text { respectively. }\end{array}$ & $\begin{array}{l}\text { The median COVID-19 } \\
\text { concern score was } 8 / 12 . \text { Most } \\
\text { responders reported being } \\
\text { satisfied with the support they } \\
\text { had received from health-care } \\
\text { professionals since the start of } \\
\text { the pandemic. }\end{array}$ \\
\hline
\end{tabular}

conducted in a tertiary-institution felt that it was not safe to visit the hospital. ${ }^{17}$ Notably, cancer patients expressed fear about the consequences and complications arising from them contracting COVID-19. ${ }^{17}$ There were emotional reactions to the prospect of not being able to say a final farewell to family and friends. ${ }^{33}$ References were also made to fears surrounding family members contracting the virus and patients expressed worries and concerns about treatment delays due to the postponement of elective procedures. ${ }^{32}$ More than half of the participants in a US study reported new-onset of anxiety or depression. ${ }^{24}$ Nearly a quarter $(23 \%$ of the 204$)$ participants in one study were in receipt of the government "shielding" advice. $^{34}$

Studies conducted in Saudi Arabia and Iran examined anxiety responses amongst children and their caregivers. $^{17,29}$ Parents reported fears surrounding COVID-19 mortality rates and expressed concerns about the high transmissibility and limited knowledge surrounding the virus. ${ }^{29}$ In one of these studies, over two-thirds of parents reported the onset of new behavioural issues amongst their children since the pandemic. ${ }^{17}$ Parents were worried about the negative effects of the pandemic on children's mental and physical health, both now and in the long-term.

\section{Adverse Impact on Personal Life, Family and Finances}

Ten studies reported consequences of the pandemic on cancer patients' personal lives, their families and the potential finances. . $^{17,22,24,28,29,32-35}$ Impact on social activities due to lockdowns was also described, with loneliness fuelling patients' worries about their cancer. ${ }^{33}$ Concerns surrounding loss of income and employment instability for cancer patients and family members were reported. ${ }^{35}$ Those receiving palliative care expressed frustration and fear at the possibility of not being able to fulfil their last wishes. ${ }^{22}$

\section{Caregiver Specific Concerns}

Concerns raised by caregivers were reported in two studies. ${ }^{22,33}$ In one study, conducted in the Netherlands, more than half of the participants reported being worried about infecting cancer patients with COVID-19. ${ }^{33}$ In another study, caregivers reported feelings of guilt due to their inability to ease their relatives' suffering and, in some cases, were reluctant to provide appropriate care (eg, changing dressings) due to worries about transmitting COVID19. ${ }^{22}$ Moreover, caregivers reported that once lockdown commenced, they experienced feelings of helplessness as social distancing impacted their ability to provide adequate care. $^{22}$

Employment uncertainty was often reported to divert caregivers' focus from caring to attempting to address the financial strain, worsening feeling of guilt. ${ }^{22}$ There were also reports of the difficulties arising from a lack of clear information and guidance about COVID-19 and its potential impact on already vulnerable cancer patients. ${ }^{22}$

\section{Developing Resilience and Coping Mechanisms}

Patient and/or carer strategies to developing resilience and coping mechanisms were described in five studies. ${ }^{19,28,29,33,35}$ For example, in one paediatric hospitalbased study, patients reported that, together with their families, they altered their attitudes towards COVID-19 nervousness and fear to regain control of living with the virus. ${ }^{29}$ In two further studies, patients emphasised their appreciation for everyday life and reported feeling content as a result of lockdown. ${ }^{28,33}$ They reported that the 
Table 3 Emerging Themes and Subthemes from Thematic Synthesis

\begin{tabular}{|c|c|}
\hline Themes & Subthemes \\
\hline $\begin{array}{l}\text { I. Experiences of accessing } \\
\text { cancer screening and diagnosis. }\end{array}$ & $\begin{array}{l}\text { - Oncology appointment } \\
\text { cancellations. } \\
\text { - Reductions in referrals. } \\
\text { - Screening non-attendance. } \\
\text { - Delays in diagnosis. }\end{array}$ \\
\hline $\begin{array}{l}\text { II. Experiences of accessing } \\
\text { cancer treatment and care } \\
\text { services. }\end{array}$ & $\begin{array}{l}\text { - Postponement/delays to } \\
\text { treatment schedules. } \\
\text { - Medicine shortages. } \\
\text { - Not allowing visitors in hospitals. } \\
\text { - Changes to the prioritisation of } \\
\text { care. } \\
\text { - Cancellations of psychological } \\
\text { counselling sessions. } \\
\text { - Changes to nursing practices. }\end{array}$ \\
\hline $\begin{array}{l}\text { III. Communication in relation to } \\
\text { cancer care. }\end{array}$ & $\begin{array}{l}\text { - Views and experiences of } \\
\text { remote consultations. }\end{array}$ \\
\hline $\begin{array}{l}\text { IV. Perceived risks of infection, } \\
\text { anxiety and fear. }\end{array}$ & $\begin{array}{l}\text { - Fear of self and family members } \\
\text { contracting the virus. } \\
\text { - Fear of incomplete cancer } \\
\text { treatment. } \\
\text { - Concerns about contracting } \\
\text { COVID-19 and the associated } \\
\text { consequences. } \\
\text { - Depression and changes in } \\
\text { cognitive and emotional } \\
\text { functioning. } \\
\text { - Government shielding letter. }\end{array}$ \\
\hline $\begin{array}{l}\text { V. Adverse impact on personal } \\
\text { life, family and finances. }\end{array}$ & $\begin{array}{l}\text { - Consequences of quarantine. } \\
\text { - Feelings of loneliness and } \\
\text { isolation. } \\
\text { - Disruption to work-life. } \\
\text { - Fulfilment of end of life wishes. }\end{array}$ \\
\hline VI. Caregivers specific concerns. & $\begin{array}{l}\text { - Stressful aspects of care giving } \\
\text { during a pandemic. } \\
\text { - Grieving the loss of a relative. } \\
\text { - Caregivers own health } \\
\text { concerns. }\end{array}$ \\
\hline $\begin{array}{l}\text { VII. Resilience and coping } \\
\text { mechanisms }\end{array}$ & $\begin{array}{l}\text { - Feelings of peace and belonging. } \\
\text { - Greater appreciation of life. } \\
\text { - Time to develop resilient } \\
\text { coping mechanisms. }\end{array}$ \\
\hline
\end{tabular}

lockdown offered them the time to reflect positively and focus on the "silver lining", creating a sense of peace which appeared to ease their worries. ${ }^{28}$ Several patients who were house bound due to their cancer reported a sense of belonging with the rest of the community being in lockdown. ${ }^{33}$

\section{Discussion}

\section{Discussion of Key Findings and Implications}

This is the first systematic review that has explored the impact of the pandemic on the experiences of cancer patients and their caregivers regarding the impact on aspects of cancer screening and care. The review has identified major recurring themes of barriers to accessing cancer screening and diagnosis; anxiety and fear; perceived risks of infection; adverse impact on personal life, family and finances; caregivers concerns and resilience; and coping mechanisms adopted by patients and carers.

The entire landscape of cancer management has changed as a result of the COVID-19 pandemic. ${ }^{36}$ This is reinforced by findings of this review which also adds to the evidence based on the experiences of patients and carers. As a result of diagnostic and treatment delays, governments and health systems are expecting a surge in the number of avoidable, cancer-related deaths. ${ }^{2}$ Participants in studies included in this review expressed concerns surrounding incomplete treatment, complications associated with contracting COVID-19 and changes to their psychological and emotional wellbeing. The suspension of cancer screening, cancellation of routine oncology appointments and postponement of treatment were linked to increased feelings of stress and anxiety; suggesting that there is a critical gap in disaster preparedness. ${ }^{37}$ Consequently, vulnerable patients were at greater risk of poor cancer outcomes, with further implications for mental health, symptom control and quality of life. For patients actively seeking end of life treatment, it was evident that strict social distancing measures limited caregiver-patient interactions and many caregivers felt disheartened that they could not provide support during this crucial time. $^{22,33}$ However, the evidence base relating to caregivers is limited, with only two studies reporting their perspectives. Further research in this key population is warranted.

Anxiety and fear, and perceived risk of infection when using cancer services were commonly reported. For example, a study conducted in Gaza reported that prior to COVID-19, only one toilet was available for public use in the oncology department and with cancer patients expressing their fears about the lack of social distancing and, close proximity. ${ }^{18}$ The World Health Organization (WHO) has also voiced concern about the lack of personal protective equipment (PPE) and drug deficit. ${ }^{38}$ The 
repercussions of resource limitations on cancer treatment outcomes outlined above needs to be explored further. ${ }^{39}$

Lessons learnt from this pandemic should become an integral part of the management of cancer patients, including those receiving palliative care, ensuring a continuum of cancer care. Future pandemic preparedness is necessary in order to minimise the disruption experienced by both cancer patients and their caregivers. Efforts should firstly be placed on restoring cancer services with the prioritisation of screening, early detection and diagnosis. As primary care is focal to diagnosis, it is vital that patients with symptoms are encouraged to present, feeling comfortable to seeking medical help and are then assessed in a timely manner. ${ }^{40}$ Remote consulting comes with many communication challenges for example, "missed cues" which would may be more apparent in face-to-face consultations.

Introducing innovations such as triage tests for patients reporting a specific set of symptoms may help to address such challenges and ensure that prompt referrals are made. $^{40}$ The consequent delay of treatment due to COVID-related measures should be considered on an individual, case by case basis for each patient; ensuring that critical patients receive adequate therapy. Alongside this, the public health implications of potentially delaying treatment versus COVID-19 prevention should be assessed.

Internationally, the professional cancer societies, including The American Society of Clinical Oncology (ASCO), have produced guidance in relation to safe provision and continuity of cancer care during the pandemic. $^{41,42}$ While this guidance advocates greater flexibility and alternative treatment options to suit patient circumstances, the impact on personal, psychological and financial wellbeing on patients need to be considered. Patient centred communications from health service providers to address patient fears of contracting the virus while on treatment and reluctance to use health services are essential.

Throughout the pandemic, it is necessary to evaluate detection rates, treatment uptake and outcomes so that valid pre-pandemic comparisons can be made. It is also imperative to consider healthcare professionals' and wider stakeholders' experiences of delivering cancer services. Roles of non-medical healthcare professionals including pharmacists can be diversified to support cancer services $^{43-45}$ including their roles in administering COVID-19 vaccination. ${ }^{46}$ Novel, faster and accurate methods of detection of symptomatic and asymptomatic
COVID-19 can minimise disruptions to the services in the future. ${ }^{46,47}$

\section{Strengths and Limitations}

The review was conducted using a rigorous and systematic approach in line with best practice. There are, however, a number of limitations. The search period was limited to one year; given the very dynamic and ever changing nature of the pandemic and the associate literature, it is possible that new studies will rapidly emerge. In synthesising data from studies conducted in a number of countries, the differing healthcare structures and processes may impact the generalisability and transferability of the findings.

\section{Conclusion}

This systematic review suggests that globally cancer patients are experiencing postponement and delays in the cancer screening and treatment, drug shortages and inadequate nursing care were commonly experienced. These factors contributed to anxiety, loneliness and fear amongst patients and carers. Lockdowns, financial issues faced by patients and patient reluctance to use services contributed to the treatment delays and cancellations. Future service models should incorporate patient and caregiver views identified from this study. Improving infection control measures and vaccination rates can bring COVID-19 infection down to manageable levels and minimise cancer service disruptions.

\section{Abbreviations}

ASCO, The American Society of Clinical Oncology; CASP, Critical Appraisal Skills Programme; NIH, National Institute of Health; PPE, personal protective equipment; PRISMA, Preferred Reporting Items for Systematic Review and Meta-analysis.

\section{Data Sharing Statement}

The data underlying this article are available in the article and https://www.dovepress.com/get supplementary file. php?f=318115.docx Supplementary Materials submitted with the manuscript.

\section{Acknowledgments}

We would like to thank the University of Birmingham Library services for their support in the search process. 


\section{Disclosure}

The authors declare that they have no conflicts of interest in this work.

\section{References}

1. National Institute of Allergy and Infectious Diseases. Coronaviruses. Available from: https://www.niaid.nih.gov/diseases-conditions/corona viruses. Accessed March 10, 2020.

2. Maringe C, Spicer J, Morris M, et al. The impact of the COVID-19 pandemic on cancer deaths due to delays in diagnosis in England, UK: a national, population-based, modelling study. Lancet Oncol. 2020;21(8):1023-1034.

3. Zhang H, Han H, He T, et al. Clinical characteristics and outcomes of COVID-19-infected cancer patients: a systematic review and meta-analysis. J Natl Cancer Inst. 2020. doi:10.1093/jnci/djaa168

4. Patt D, Gordan L, Diaz M, et al. Impact of COVID-19 on cancer care: how the pandemic is delaying cancer diagnosis and treatment for American seniors. JCO Clin Cancer Info. 2020;4:1059-1071. doi:10.1200/CCI.20.00134

5. Cancer Research UK. 2000 fewer people in England began cancer treatment in January. Available from: https://www.cancerre searchuk.org/about-us/cancer-news/news-report/2021-03-11-2000fewer-people-in-england-began-cancer-treatment-in-january. Accessed April 12, 2021.

6. Gheorghe A, Maringe C, Spice J, et al. Economic impact of avoidable cancer deaths caused by diagnostic delay during the COVID-19 pandemic: A national population-based modelling study in England, UK. Eur J Cancer. 2021;152:233-242.

7. Neal RD, Tharmanathan P, France B. Is increased time to diagnosis and treatment in symptomatic cancer associated with poorer outcomes? Systematic review. Br J Cancer. 2015;112(suppl 1):S92S107. doi:10.1038/bjc. 2015.48

8. Burki TK. Cancer guidelines during the COVID-19 pandemic. Lancet Oncol. 2020;21(5):629-630. doi:10.1016/S1470-2045(20)30217-5

9. Yorkshire Evening Post. Leeds mum diagnosed with stage four cancer months after screening was cancelled due to Covid. Available from: https://www.yorkshireeveningpost.co.uk/health/leeds-mumdiagnosed-stage-four-cancer-months-after-screening-was-cancelleddue-covid-3038701. Accessed July 20, 2021

10. Macmillan Cancer Support. 'The forgotten 'C'? The impact of COVID-19 on cancer care. Available from: https://www.macmillan. org.uk/assets/forgotten-c-impact-of-covid-19-on-cancer-care.pdf. Accessed July 20, 2021

11. Hartman HE, Sun Y, Devasia TP, et al. Integrated survival estimates for cancer treatment delay among adults with cancer during the COVID-19 pandemic. JAMA Oncol. 2020;6(12):1881-1889. doi:10.1001/jamaoncol.2020.5403

12. Carreira H, Strongman H, Peppa M, et al. Prevalence of COVID-19related risk factors and risk of severe influenza outcomes in cancer survivors: a matched cohort study using linked English electronic health records data. eClinicalMedicine. 2020;29:100656. doi:10.10 16/j.eclinm.2020.100656

13. Moher D, Liberati A, Tetzlaff J, Altman DG, Prisma Group. Preferred reporting items for systematic reviews and meta-analyses: the PRISMA statement. PLoS Med. 2009;6(7):e1000097. doi:10.1371/ journal.pmed.1000097

14. Lucas PJ, Baird J, Arai L, Law C, Roberts HM. Worked examples of alternative methods for the synthesis of qualitative and quantitative research in systematic reviews. BMC Med Res Method. 2007;7 (1):1-7. doi:10.1186/1471-2288-7-4

15. Critical Appraisal Skills Programme. Critical appraisal skills programme (CASP) checklists. Available from: https://casp-uk.net/casptools-checklists/. Accessed March 15, 2021.
16. National Heart, Lung and Blood Institute. Quality assessment tool for observational cohort and cross-sectional studies. Available from: https://www.nhlbi.nih.gov/health-topics/study-quality-assessmenttools. Accessed November 05, 2020.

17. AlShahrani M, Elyamany G, Sedik Q, et al. The impact of COVID-19 pandemic in children with cancer: a report from Saudi Arabia. SAGE Open. 2020. doi:10.1177/1178632920984161

18. AlWaheidi S, Sullivan R, Davies EA. Additional challenges faced by cancer patients in Gaza due to COVID- 19. eCancer Med Sci. 2020;14:ed100. doi:10.3332/ecancer.20202.ed.100

19. Casanova M, Pagani Bagliacca E, Silva M, et al. How young patients with cancer perceive the COVID-19 (coronavirus) epidemic in Milan, Italy: is there room for other fears? Pediatr Blood Cancer. 2020;67 (7):e28318. doi:10.1002/pbc.28318.

20. de Joode K, Dumoulin DW, Engelen V, et al. Impact of the Coronavirus disease 2019 pandemic on cancer treatment: the patients' perspective. Eur $J$ Cancer. 2020;136:132-139. doi:10. 1016/j.ejca.2020.06.019

21. Desideri I, Ciccone PL, Stocchi G, et al. Impact of COVID-19 on patient-doctor interaction in a complex radiation therapy facility. Support Care Cancer. 2020:1-7. doi:10.1007/s00520-020-05793-3.

22. Dhavale P, Koparkar A, Fernandes P. Palliative care interventions from a social work perspective and the challenges faced by patients and caregivers during COVID-19. Indian J Palliat Care. 2020;26 (5):58-62. doi:10.4103/IJPC.IJPC_149_20

23. Falcone R, Grani G, Ramundo V, et al. Cancer care during COVID-19 era: the quality of life of patients with thyroid malignancies. Front Oncol. 2020. doi:10.3389/fonc.2020.01128.24

24. Frey MK, Ellis AE, Zeligs K, et al. Impact of the coronavirus disease 2019 pandemic on the quality of life for women with ovarian cancer. Am J Obstet Gynecol. 2020;223(5):725-e1. doi:10.1016/j.ajog.20 20.06.049

25. Ghosh J, Ganguly S, Mondal D, Pandey P, Dabkara D, Biswas B. Perspective of oncology patients during COVID-19 pandemic: a prospective observational study from India. J Glob Oncol. 2020;6 (6):844-851. doi:10.1200/GO.20.00172

26. Greco F, Altieri VM, Esperto F, Mirone V, Scarpa RM. Impact of COVID-19 pandemic on health-related quality of life in uro-oncologic patients: what should we wait for? Clin Genitourin Cancer. 2020. doi:10.1016/j.clgc.2020.07.008

27. Guven DC, Sahin TK, Aktepe OH, Yildirim HC, Aksoy S, Kilickap S. Perspectives, knowledge, and fears of cancer patients about COVID-19. Front Oncol. 2020;10:1553. doi:10.3389/ fonc. 2020.01553

28. Hyland KA, Jim HSL. Behavioural and psychosocial responses of people receiving treatment for advanced lung cancer during the COVID-19 pandemic: a qualitative analysis. Psycho-Oncol. 2020;29 (9):1387-1392. doi:10.1002/pon.5445

29. Mirlashari J, Ebrahimpour F, Salisu WJ. War on two fronts: experience of children with cancer and their family during COVID-19 pandemic in Iran. $J$ Pediatr Nurs. 2021;57:25-31. doi:10.1016/j. pedn.2020.10.024

30. Mitra M, Basu M. A study on challenges to health care delivery faced by cancer patients in India during the COVID-19 pandemic. J Prim Care Community Health. 2020;11:1-5. doi:10.1177/215013272 0942705

31. Papautsky EL, Hamlish T. Patient-reported treatment delays in breast cancer care during the COVID-19 pandemic. Breast Cancer Res Treat. 2020;184(1):249-254. doi:10.1007/s10549-020-05828-7

32. Qian Y, Wu K, Xu H, et al. A survey on physical and mental distress among cancer patients during the COVID-19 epidemic in Wuhan, China. J Palliat Med. 2020;23(7):888-889. doi:10.1089/jpm.2020. 0240

33. Schellekens MPJ, van der Lee M. Loneliness and belonging: exploring experiences with the COVID-19 pandemic in psycho-oncology. Psycho-Oncol. 2020;29(9):1399-1401. doi:10.1002/pon.5459 
34. Swainston J, Chapman B, Grunfeld EA, Derakshan N. COVID-19 lockdown and its adverse impact on psychological health in breast cancer. Front Psychol. 2020;11:2033. doi:10.3389/fpsyg.2020.62 6038

35. Younger E, Smrke A, Lidington E, et al. Health-related quality of life and experiences of sarcoma patients during the COVID-19 pandemic. Cancers. 2020;12(8):2288. doi:10.3390/cancers 12082288

36. Jones D, Neal RD, Duffy SRG, Scott SE, Whitaker KL, Brain K. Impact of the COVID-19 pandemic on the symptomatic diagnosis of cancer: the view from primary care. Lancet Oncol. 2020;21(6):748-750. doi:10.1016/S1470-2045(20) 30242-4

37. International Federation of Red Cross and Red Crescent. Disaster preparedness. Available from: https://media.ifrc.org/ifrc/what-we-do/dis aster-and-crisis-management/disaster-preparedness/. Accessed April 02, 2021.

38. World Health Organisation. Occupied Palestinian territory COVID-19 response plan 2020. Available from: https:// www.who.int/health-cluster/countries/occupied-palestinianterritory/Occupied-Palestinian-Territory-COVID-19-Humanitarian -Response-Plan-April-2020.pdf?ua=1. Accessed July 20, 2021. Accessed April 15, 2021.

39. Jazieh AR, Akbulut H, Curigliano G, et al. Impact of the COVID-19 pandemic on cancer care: a global collaborative study. JCO Glob Oncol. 2020;6:1428-1438. doi:10.1200/GO.20.00351

40. Neal RD, Nekhlyudov L, Wheatstone P, Koczwara B. Cancer care during and after the pandemic. Br Med J. 2020;370:m2622. doi:10.1136/bmj.m2622

41. NHS England. NHS England interim treatment options during the COVID-19 pandemic. Available from: https://www.nice.org.uk/gu dance/ng161/resources/interim-treatment-change-options-during-thecovid19-pandemic-endorsed-by-nhs-england-pdf-8715724381. Accessed July 20, 2021
42. American Society Clinical Oncology, (ASCO). ASCO special report: a guide to cancer care delivery during the COVID-19 pandemic. Available from: https:/www.asco.org/sites/new-www.asco.org/files/ content-files/2020-ASCO-Guide-Cancer-COVID19.pdf. Accessed April 28, 2021.

43. Hussain AZ, Paudyal V, Hadi MA. Impact of the COVID-19 pandemic on the prescribing patterns of first-line antibiotics in english primary care: a longitudinal analysis of national prescribing dataset. Antibiotics. 2021;10(5):591. doi:10.3390/antibiotics10050591

44. Paudyal V, Sun S, Hussain R, Abutaleb MH, Hedima EW. Complementary and alternative medicines use in COVID-19: A global perspective on practice, policy and research. Research in Social and Administrative Pharmacy. 2021. doi:10.1016/j. sapharm.2021.05.004

45. Paudyal V, Cadogan C, Fialová D, et al. Provision of clinical pharmacy services during the COVID-19 pandemic: experiences of pharmacists from 16 European countries. Res Soc Administrative Pharm. 2020;30:46.

46. Paudyal V, Fialová D, Henman MC, Hazen A, Okuyan B, Lutters M, Cadogan C, Da Costa FA, Galfrascoli E, Pudritz YM, Rydant S. Pharmacist's involvement in COVID-19 vaccination across Europe: a situational analysis of current practice and policy. International Journal of Clinical Pharmacy. 2021. https://doi.org/10.1007/s11096021-01301-7.

47. Manigandan S, Wu MT, Ponnusamy VK, Raghavendra VB, Pugazhendhi A, Brindhadevi K. A systematic review on recent trends in transmission, diagnosis, prevention and imaging features of COVID-19. Process Biochem. 2020;98:233-240. doi:10.1016/j. procbio.2020.08.016

48. Islam MM, Karray F, Alhajj R, Zeng J. A review on deep learning techniques for the diagnosis of novel coronavirus (covid-19). IEEE Access. 2021;9:30551-30572. doi:10.1109/ACCESS.2021.3058537
Cancer Management and Research

\section{Publish your work in this journal}

Cancer Management and Research is an international, peer-reviewed open access journal focusing on cancer research and the optimal use of preventative and integrated treatment interventions to achieve improved outcomes, enhanced survival and quality of life for the cancer patient.

\section{Dovepress}

The manuscript management system is completely online and includes a very quick and fair peer-review system, which is all easy to use. Visit http://www.dovepress.com/testimonials.php to read real quotes from published authors. 